\title{
Entry and competitive dynamics in the mobile telecommunications market
}

\author{
Zi-Lin He ${ }^{\mathrm{a}, 1}$, Kwanghui Lim ${ }^{\mathrm{b}, *}$, Poh-Kam Wong ${ }^{\mathrm{c}, 2}$ \\ a Department of Management, University of Otago, P.O. Box 56, Dunedin 9001, New Zealand \\ ${ }^{\mathrm{b}}$ Melbourne Business School, 200 Leicester Street, Carlton, Vic. 3053, Australia \\ ${ }^{\mathrm{c}}$ NUS Entrepreneurship Centre, National University of Singapore, E3A Level 6, \\ 10 Kent Ridge Crescent, Singapore 119260, Singapore
}

Available online 11 October 2006

\begin{abstract}
We propose an extension of the Gans-Stern [Gans, J.S., Stern, S., 2003. The product market and the market for "ideas": commercialization strategies for technology entrepreneurs. Research Policy 32 (2), 333-350] framework that includes entry by existing firms. An incumbent firm possessing complementary assets and strong appropriability is in a formidable position [Teece, D.J., 1986. Profiting from technological innovation: implications for integration, collaboration, licensing, and public policy. Research Policy 15 (6), 285-305]. However, a de alio entrant can leverage complementary assets to enter along a new technological trajectory, and then develop appropriability. We illustrate how several mobile telecommunications firms (Ericsson, Nokia and Samsung) pursued this strategy to catch up with the market leader (Motorola). We also identify several shortcomings in Motorola's approach: it was too inward-looking in developing technologies, but ironically not inward-looking enough in exploiting its most valuable patents. (C) 2006 Elsevier B.V. All rights reserved.
\end{abstract}

Keywords: Patent citations; Knowledge flows; Mobile telecommunications; Intellectual property; Complementary assets

\section{Introduction}

In this paper, we explore the role of intellectual property, complementary assets and knowledge flows in enabling several entrant firms to catch up with Motorola, the early leader in the mobile telecommunications market. Motorola initially enjoyed strong appropriability over intellectual property (through patents) and possessed the necessary complementary assets (manufacturing, distribution, access to customers, branding and services). Based on Teece (1986), this meant Motorola

\footnotetext{
* Corresponding author. Tel.: +61 393498294.

E-mail addresses: zilinhe@ business.otago.ac.nz (Z.-L. He), k@kwanghui.com (K. Lim), bizwpk@nus.edu.sg (P.-K. Wong).

1 Fax: +64 34798173

2 Fax: +6567732269 .
}

was in an enviable position to capture the returns from its innovations. It is therefore surprising that other firms including Ericsson and Nokia were subsequently able to challenge and even overtake Motorola in the mobile telecommunications market. Why did Motorola stumble, and what strategies did these firms use to compete against it? What lessons does this hold for managers and scholars?

We take the entrant's point of view to consider one strategy by which a challenger might catch up with (and possibly overtake) an incumbent controlling both intellectual property and complementary assets. While a de novo firm will find it difficult to compete, a de alio entrant can leverage its complementary assets to enter along a new technological trajectory, then use this beachhead to strengthen its intellectual property position. Building upon the knowledge of incumbent firms and other exter- 
Table 1

Global market share of mobile phones (\%)

\begin{tabular}{lrrrrrrrrrr}
\hline & $1996^{\mathrm{a}}$ & 1997 & 1998 & 1999 & 2000 & 2001 & 2002 & 2003 & 2004 & 2005 \\
\hline Motorola & 27.0 & 28.8 & 23.2 & 16.9 & 14.6 & 14.8 & 15.3 & 14.5 & 15.0 & 17.9 \\
Nokia & 21.0 & 20.1 & 24.3 & 26.9 & 30.6 & 35.0 & 35.8 & 34.7 & 29.7 & 31.8 \\
Ericsson $^{\mathrm{b}}$ & 12.0 & 16.2 & 14.4 & 10.5 & 10.0 & 6.7 & $6.7^{\mathrm{c}}$ & $5.1^{\mathrm{c}}$ & $6.1^{\mathrm{c}}$ & $6.0^{\mathrm{c}}$ \\
Samsung $^{\mathrm{c}}$ & 1.0 & 3.6 & 4.2 & 6.2 & 5.0 & 7.1 & 9.8 & 10.5 & 12.4 & 12.2 \\
\hline
\end{tabular}

Source: Deutsche Bank (for 2001), IDATE Mobile (for 2004, 2005), Gartner Dataquest (for all other years).

a Market share data is not available prior to 1996. However Motorola dominated both mobile phones and infrastructure prior to the period shown (Steinbock, 2003, Chapter 8).

b Ericsson overtook Motorola in mobile infrastructure around 1996. Market share data for mobile infrastructure is not available. However, we found rankings of mobile infrastructure market share for a number of years: 1997 (Ericsson, Motorola, Nokia, Lucent, Nortel); 1999 (Ericsson, Lucent, Motorola, Nokia, Nortel); and 2005 (Ericsson, Nokia, Siemens, Motorola, Nortel). Source: Burnham (2002) and IDATE (2006).

c For Sony-Ericsson.

nal sources is a key ingredient to this strategy, so that the attacker can rapidly develop a defensible intellectual property position.

To illustrate this strategy, we present a case study of the mobile telecommunications market, which includes the manufacture and sale of handsets and infrastructure equipment for mobile telecommunications. ${ }^{3}$ Ericsson overtook Motorola in terms of mobile telecommunications infrastructure around 1996, while Nokia overtook Motorola in the mobile handset market around 1998 (see Table 1). Samsung is a successful recent entrant: while it held only $4.2 \%$ of the global market for mobile handsets in 1998, by 2004 it had become the third largest firm in terms of market share. Our study uses both quantitative analysis of intellectual property development and qualitative analysis of overall firm strategy (Yin, 1994). In particular, our qualitative research (based on news and company reports, books and a handful of interviews) suggests that the challengers relied initially upon complementary assets to enter the market. This intuition is reinforced by our quantitative analysis of US patents granted to these firms between 1976 and 2004, which shows that the attacking firms only began to patent aggressively after they had become major threats to the incumbent, implying that they initially relied on complementary assets and other means to catch up, rather than building a strong arsenal of intellectual property to challenge the incumbent. The quantitative analysis also shows that attacking firms relied heavily on knowledge

\footnotetext{
${ }^{3}$ Our study focuses on the mobile telecommunications market, rather than on the broader mobile telecommunications industry, which also includes upstream semiconductor suppliers, downstream carriers and service providers (e.g. AT\&T) and firms specializing in content and multimedia. In 2005, the global mobile phone market was estimated at US\$ 110 billion, while the mobile network equipment market was around US\$ 34 billion (source: IDATE, 2006).
}

spillovers from the leader and other external sources to create their own patented innovations, and that only after becoming a leader did the attacking firm begin to reduce its reliance on the former leader and to develop a strong patent portfolio.

Motorola's failure to sustain its leadership position is often blamed on its failed attempt to commercialize its Iridium mobile network based on satellite technology (e.g. see Finkelstein and Sanford, 2000 and Lashinsky, 2004) as well as on fears of cannibalization and organizational issues (Macher and Richman, 2004). Through our regression analysis, we offer additional reasons for why Motorola might have lost its market leadership position. Firstly, Motorola was more inward-looking in developing its technology than its key competitors. This is reflected by Motorola's high self-citations rates, even after controlling for its larger share of mobile patents. As such, Motorola may have been less sensitive towards the latest technical change and its competitors' moves. Secondly, Motorola was paradoxically not inward-looking enough where its own high impact patents are concerned. Ericsson and Nokia generated many inventions that built upon Motorola's core patents, and seemingly more so than Motorola: many of Motorola's most valuable patents were cited more heavily by its competitors than by Motorola itself. If self-citation is an important indicator of a firm's capability to appropriate the returns from its inventions as suggested by Trajtenberg et al. (1997), Motorola did not do enough to exploit its core technologies.

Our results lead us to suggest refinements to existing management models. In industries such as telecommunications, it is difficult to compete head-on with the existing market leader. One possible strategy for a challenger to pursue is to leverage its complementary assets to exploit a new technological trajectory (e.g. during the transition from $1 \mathrm{G}$ to $2 \mathrm{G}$ in mobile telecoms), and then 
reinforce its attack by developing unique technological capabilities. Building upon the knowledge of incumbent firms and other external sources is essential, so that the attacker does not end up being just a "copycat", but instead is able to rapidly develop a sustainable business based on innovative technologies that it can patent and defend. Such a strategy may only be feasible for entrants that already have complementary assets (as is the case with Ericsson, Nokia and Samsung). Further work is needed to explore under what conditions this approach works, and whether alternative strategies are also viable. From the perspective of the incumbent, our analysis shows that possessing intellectual property and complementary assets is not enough: the firm should aggressively exploit its own technological "crown jewels" and monitor whether rivals are also doing so.

In the next section of this paper, we explore the dynamics of market entry and how it relates to Teece (1986) and the Gans-Stern (2003) framework. We then illustrate the strategy described above in the context of the mobile telecommunications market. Section 3 describes the data and methodology used for our quantitative analysis, Section 4 presents the results, and Section 5 contains a discussion and our conclusions.

\section{The dynamics of entry and catch up}

Many studies have examined why incumbent firms in technology-intensive markets may lose their dominant positions to entrants. One major issue is the reluctance of incumbent firms to cannibalize rents from older technologies when faced with newer ones (Reinganum, 1983; Arrow, 1962). Other factors include organizational inertia (Hannan and Freeman, 1984), "competencedestroying" innovation which causes the skills of the incumbent to become obsolete (Tushman and Anderson, 1986), and architectural innovation which may delay the incumbent's response due to its entrenched problem solving routines (Henderson and Clark, 1990). When the environment changes, a firm could fall into competency traps (Levitt and March, 1988) and see their core capabilities transform into rigidities (Leonard-Barton, 1995).

The early literature viewed entry as head-on technological competition between entrant and incumbent, including the sizeable stream of research on patent races (e.g. Gilbert and Newbery, 1982). Teece (1986) added complementary assets as an important dimension to consider alongside patents and intellectual property, thereby suggesting that the returns to $R \& D$ are a function of both intellectual property and complementary assets. According to Teece, complementary assets may include competitive manufacturing, distribution, service and com- plementary technologies. One approach for competitors/imitators to catch up with an innovator is by deploying superior complementary assets (Teece, 1986, pp. 285-290). Complementary assets are especially important for challenger firms when appropriability is weak and during the later stages of a technology, after the emergence of a "dominant design" (pp. 291-292). Another important insight from Teece (1986) that deviates from the earlier literature is that it is sometimes better for the competing firm to cooperate with the innovator, for example through contracts and licensing agreements, rather than trying to compete head-on, particularly when the innovator has strong appropriability over its technology and the complementary assets are available in competitive supply (Teece, 1986, p. 293).

The conditions that shape competition and cooperation are further examined by Gans et al. (2002). A key insight from their work is that industry conditions (the strength of intellectual property protection and who owns complementary assets) affect market-level outcomes: the probability of entrepreneurial firms cooperating with industry incumbents, and therefore how they might enter specific market segments. The choice is about "entering the product market-a competition strategy, or selling the innovation to an incumbent-a cooperation strategy" (Gans et al., 2002, p. 573).

Gans and Stern (2003) developed this insight into a valuable conceptual model of how entrepreneurial firms can commercialize new technologies. As illustrated in Fig. 1, industries where the entrant possesses strong appropriability while the incumbent controls complementary assets (such as biotechnology) offer the best chance for an "ideas factory" to emerge, in which the entrant cooperates with the incumbent. In industries with strong appropriability and in which incumbent firms do not control critical complementary assets, the entrant can compete head-on ("greenfield competition"). In industries with weak appropriability and in which incumbents do not control the complementary assets, the entrant faces a level playing field and should quickly develop competence-destroying innovations (the "attacker's advantage"). Finally, in industry with weak appropriability and in which existing firms control critical complementary assets, the entrant is in a very vulnerable position. In such situations, the incumbent can re-engineer its own version of the entrant's idea, hence cooperation is rare and can only occur if the incumbent is willing to invest in building a reputation for cooperation.

Do other opportunities exist for entry when the incumbent has a strong intellectual property position and owns many of the complementary assets? An assumption in 


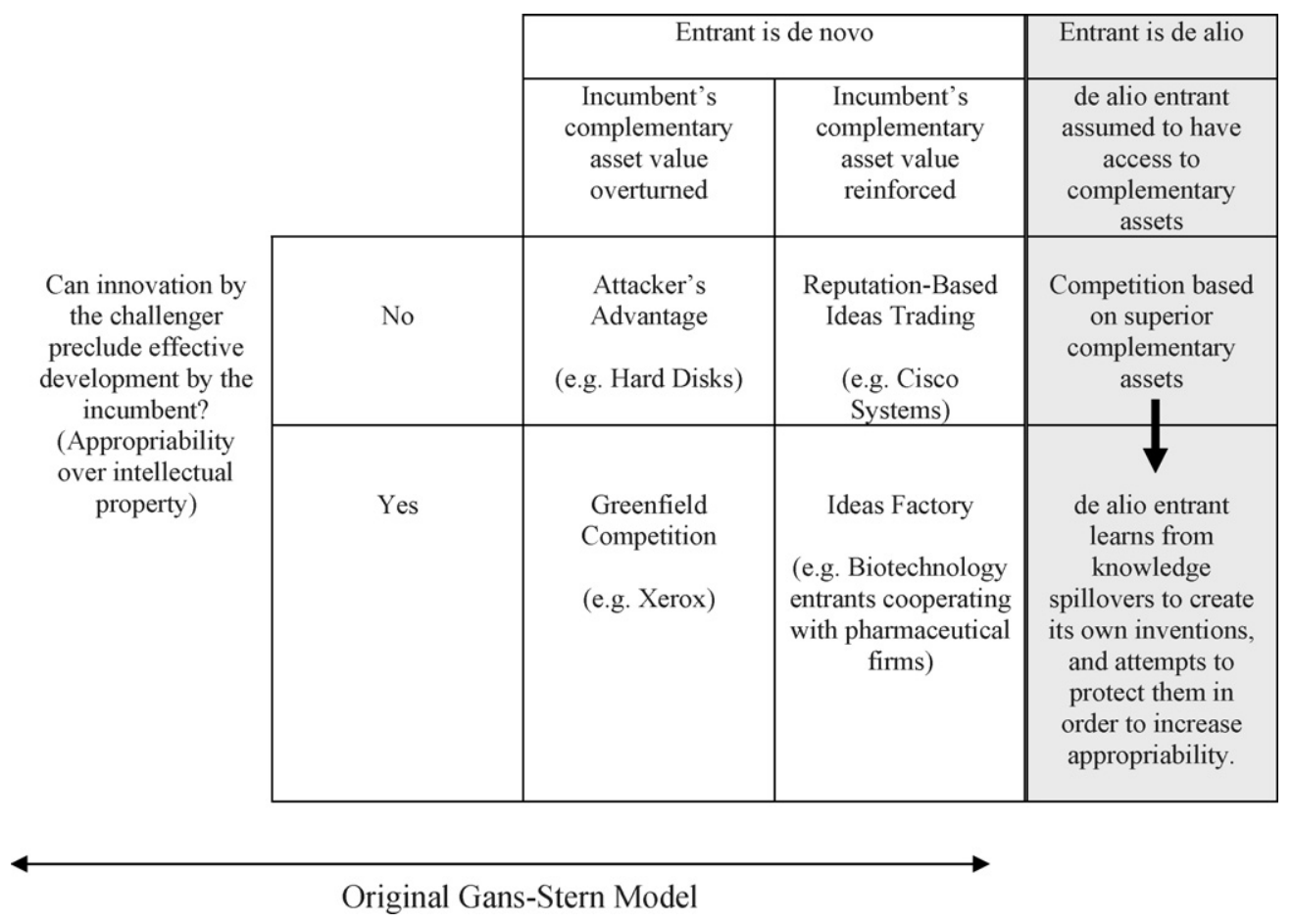

Fig. 1. Proposed extension of the Gans-Stern model (Research Policy, 2003).

the Gans-Hsu-Stern model is that the entrant is de novo and joins the market as an entrepreneurial startup, with a valuable invention but few complementary assets (these are owned by the incumbent). We propose that their framework can be usefully enhanced by also considering de alio entry, or entry by existing firms. Research shows that the pre-entry experience of such firms can improve their survival rates when entering new markets (Agarwal et al., 2004; Carroll et al., 1996; Helfat and Lieberman, 2002; Klepper and Simons, 2000). Unlike de novo entrants, de alio entrants have access to personnel, technology and other complementary assets that are beneficial especially in the initial stages of entry (Carroll et al., 1996), although they may be hampered by inherited organizational routines (Khessina, 2002). While prior research has usefully focused on comparing the performance of de novo and de alio entrants, an implication of Gans and Stern (2003) is that de novo entry is rare when the incumbent firm has strong positions with regards to both intellectual property and complementary assets. We suspect that when both of these are costly and difficult to acquire, de alio entry may be the only feasible entry mode.

Our proposed extension to the Gans-Stern framework is illustrated in Fig. 1. The de alio firm enters a market by leveraging its existing complementary assets. This allows it to develop an initial beachhead in the market, and is consistent with Teece's (1986) idea of competing through superior complementary assets. The alternative strategy - of initially building an intellectual property portfolio to trade with the incumbent or to compete with it directly - is risky and does not make use of the de alio entrant's prior strengths. In addition, developing a strong intellectual property portfolio may take time, especially given the cumulative nature of knowledge and the incumbent's head start in R\&D. In attempting entry, it would additionally benefit the de alio firm to ride upon a new technological wave, particularly if the new technology is competence-destroying (Tushman and Anderson, 1986) or serves a market with new demand conditions (Adner, 2002; Christensen and Bower, 1996).

After establishing an initial market beachhead, the challenger's main worry is sustainability. In technologyintensive markets it is difficult to compete head-on against an incumbent with high appropriability, just by owning complementary assets. According to Teece (1986, Fig. 11), in such situations the incumbent will win, although it may have to share some of its profits with the complementary asset holder. In order to catch up with (or even surpass) the incumbent, we propose that the challenger should rapidly build up a defensible intellectual property portfolio of its own, moving from the top-right to the bottom-right area of Fig. 1. To do so fairly quickly, it has to rely extensively on knowledge 
spillovers from the incumbent as well as other sources (universities, research consortia, other firms). Being focused on learning from the best available external technology, including the technological "crown jewels" of the incumbent, is important. This will allow the challenger firm to create novel, valuable inventions that it can patent and defend. Thus, the challenger should not just be a copycat or rely exclusively on complementary assets, but should build new and innovative products and services in order to compete effectively. For this strategy to work, the initial resource endowment of the de alio firm has to be carefully used to create the initial foothold in the market and subsequently invested into the R\&D required to build up a strong intellectual property portfolio.

Below, we illustrate how several firms in the mobile telecommunications market used this approach to overcome the initially formidable position held by Motorola in mobile telecommunications. ${ }^{4}$ We emphasize that we offer an illustration, not a "proof". Future work will be needed to examine whether this strategy is applicable in other settings, and whether other strategies are feasible. In the remainder of this section, we summarize the strategies pursued by each firm attempting to catch up with the incumbent. This analysis is based on news and company reports, prior research studies, books, and a small number of interviews with executives.

\subsection{The mobile telecommunications market ${ }^{5}$}

The mobile telecommunications market presents an interesting case of entry consistent with the approach described above. Both intellectual property and complementary assets are important for mobile telecommunications. Patent disputes during the 1980s between Motorola, Nokia and Tandy emphasized the importance of intellectual property to the market participants (Steinbock, 2001, p. 188). Complementary assets of importance in this competitive setting include manufac-

\footnotetext{
${ }^{4}$ It might be argued that Ericsson, Nokia and Samsung are not strictly de alio entrants. This largely depends on how broadly one defines the "market". As discussed in Section 2.1, Ericsson and Nokia began producing analog mobile cell phones around 1981, while Samsung began around 1983. Prior to this, Nokia and Samsung operated in other industries and other segments of the telecommunications industry. Ericsson began producing radio equipment around 1919, so it is debatable whether it was a de alio entrant or a non-entrant. However, all three firms were "existing" firms at the point of entry into mobile cell phones and equipment, not de novo entrants.

5 This section draws upon the work of Steinbock (2001, 2003), Ong and Jeden (2002), Echikson (1994), Adner (2003), Lashinsky (2004), and various online sources and company websites.
}

turing capability, complementary technologies, branding and marketing. The strong need for interoperability and more recently, multimedia content, implies that network externalities are probably important (McGahan et al., 1997). Hence, access to an installed base of users is also important. Access to telecommunications markets is geographically segmented, and as seen below, access to these markets is shaped by government policies, prior experience operating in various markets, as well as strategic partnerships.

The early leader in both mobile handsets and infrastructure was Motorola. It remained dominant till the late 1990s, after which Ericsson, Nokia and Samsung caught up with it. We observe no de novo entrants that became highly successful in the mobile telecommunications market. ${ }^{6}$ However, a number of de novo entrants did emerge upstream and downstream; they cooperated with the incumbents as "ideas factories". For example, Qualcomm pioneered a new type of technology (spread spectrum or CDMA) and its main commercialization strategy was to license this intellectual property to many mobile telecommunications firms. Downstream entrants include those providing multimedia content for mobile telephony and telecommunications services firms.

Motorola was founded in Chicago, Illinois, in 1928. It began as a supplier of car radios and two-way police radios. With the help of large military contracts during the World War II, Motorola expanded into semiconductor, microprocessor chips, electronics, satellite communications, and telecommunication. Motorola pioneered and dominated analog (1G) mobile technology. In 1973, it demonstrated the DynaTAC, the world's first commercial portable telephone; in 1989, it introduced the MicroTAC, which was the smallest and lightest mobile phone on the market at that time. Unfortunately, Motorola was slow to make the transition from $1 \mathrm{G}$ to 2G (digital) technology (Macher and Richman, 2004). After digital mobile phones took off, Motorola attempted to address the market with its own digital phones, but it was too late and a large share of the market was competed away by Nokia and Ericsson. ${ }^{7}$ By year 2000, Motorola's

\footnotetext{
${ }^{6}$ As of 2001, the firms with the largest market shares worldwide in mobile telephony were Nokia (35\%), Motorola (15\%), Ericsson (7\%), Samsung (7\%), Siemens (7\%), Kyocera (4\%), Panasonic (4\%) and others $(21 \%)$. Source: Micrologic Research.

${ }^{7}$ Motorola continued to rely heavily on analog mobile phone models, so it even lost market leadership in its home country in 1997 when Ericsson and Nokia became No. 1 and 2, respectively, in the US market (Collis, 1999). In 1998 when AT\&T initiated the massive rollout of its Digital One Rate plan, Motorola did not even have a digital mobile phone ready.
} 
market share of mobile handsets slid to only around $15 \%$ (Table 1). Moreover, its US\$ 5 billion investment into its Iridium satellite-based mobile telephony system ended up a failure (Finkelstein and Sanford, 2000). Around 1999, Motorola went through a series of reorganization efforts (BusinessWeek, 1998), changing its strategy in the new millennium so that it is only now starting to regain market share.

Ericsson's history dates back to 1876 when Lars Magnus Ericsson opened a small repair workshop for telegraph equipment in central Stockholm. It grew into a leading manufacturer of telephone equipment. Its initial entry into radio-based telephony was due to a 1919 stake in SRA, a Swedish company that built radio transmitters and receivers (Steinbock, 2003, p. 255). In 1981, it began to build mobile telephone networks based on analog (1G) technology, the NMT450. In the 1990s, two factors helped Ericsson to develop a strong position in mobile telecommunications. Firstly, the European Union decided to support GSM (Global System for Mobile Communications, a key 2G cellular standard) and this helped Ericsson to capture worldwide leadership in mobile infrastructure equipment, with a 40\% market share around 1996. Secondly, Ericsson was able to leverage its strength in complementary technologies to expand its share of the mobile phone market (Steinbock, 2003, Chapter 9). Ericsson initially focused on the fixed line infrastructure equipment, but later entered the mobile infrastructure business after Motorola demonstrated its commercial viability. Ericsson's sales of fixed line infrastructure equipment gave Ericsson access to many diverse geographic markets including Saudi Arabia, Taiwan (where it put in place the world's largest paging system) and the United States. Interestingly, it initially entered the US market in the 1980s through joint ventures and partnerships as an equipment supplier, and only after becoming dominant in that sector did it begin selling mobile phones through a successful joint venture with General Electric (Steinbock, 2003, p. 262). Unfortunately, toward the end of the 1990s, Ericsson's market position in mobile handsets eroded due to a misplaced strategic bet on "the office of the future". In April 2001, Ericsson announced job cuts of 12, 000, or $11 \%$ of its staff (Economist, 2001). The mobile phone unit merged with Sony's in October 2001. In contrast to mobile phones, Ericsson has been more successful in selling mobile infrastructure, and it was the leading producer of mobile infrastructure between 1997 and 2005 (IDATE, 2006).

Nokia was founded in Finland in 1865 as a paper mill. The merger of three Nokia constituent companies during 1966-1967 gave birth to an industrial conglomer- ate with five major business divisions-forestry, rubber, cable, electronics, and electricity generation. By 1987, consumer electronics had become Nokia's largest business area, but in the early 1990s it was forced by economic difficulties to drop other activities and focus on mobile telecommunications (Steinbock, 2001, p. 81). Nokia started making mobile phones in 1981. Like Ericsson, Nokia benefited from its involvement in the analog NMT mobile phone system in the 1980s and the EU decision to make GSM technology mandatory in Europe (Burgelman and Meza, 2003). By 1991, Nokia had become Europe's largest and the world's second largest mobile phone manufacturer. In 1998, Nokia surpassed Motorola to become the world leader in mobile phones. It is reported that Nokia's success is due to the innovative designs of its phones and strong branding and marketing, particularly following a ramp-up in the 1993-1995 timeframe (Adner, 2003; Steinbock, 2001, pp. 269-279). According to Steinbock (2001, p. 140), Nokia pursued a strategy of commercializing "disruptive" technologies and using these to penetrate global markets by entering new niches, and then expanding beyond these niches. As an aggressive competitor, Nokia rolled out more than 30 new mobile phone models during the 12 months between July 1997 and July 1998 (Collis, 1999).

Samsung is a diversified Korean conglomerate, with a strong presence in electronics and telecommunications. Samsung Electronics was founded in 1969 and is now one of the largest manufacturers in Korea. Samsung's competitive advantage lies in its formidable manufacturing capability and its ability to compete on low cost (Yu, 1998). It began developing mobile phones in 1983, with the first product shipped around 1988 (Lee and Lee, 2004). Starting around 1994, it embarked upon a strategy of combining low prices with heavy advertising. This included TV advertisements featuring famous actors and sending executives to visit distributors across Korea to persuade them to switch from Motorola (then the market leader with around $52 \%$ of the Korean market) to Samsung. As a result, Samsung increased its share of the Korean mobile phone market from $25.8 \%$ in 1994 to 51.5\% in 1995 (Lee and Lee, 2004). It later expanded this branding strategy globally, sponsoring events such as the 1996 and 2000 Olympics, and incorporating product placements into popular movies like The Matrix (Lee and Lee, 2004). However, it only became highly successful in mobile telephony after 2000, during the transition from $2 \mathrm{G}$ to $3 \mathrm{G}$ technology that emphasizes multimedia. This is complementary to its core technological strengths in electronics: LCD panels, television technology and video processing technology (Euromonitor, 2005). In 1999, Samsung launched the world's first mobile phone 
incorporating a television, and in 2000 it launched the world's first mobile phone with built-in videoconferencing capabilities (BusinessWeek, 2000).

These company profiles illustrate how complementary assets (branding, complementary technologies, access to customers in new markets) facilitated entry by firms riding waves of new mobile telecommunications technologies. Each firm was not a de novo entrant, but brought with it skills, customers, and expertise from the past. In the next section, we dig deeper to explore how the intellectual property portfolio of each firm and patterns of knowledge flows shaped the competitive dynamics of the market.

\section{Data and method}

Our dataset consists of US patents issued to Motorola, Ericsson, Nokia and Samsung by the US Patent and Trademark Office (USPTO) from 1976 to 2004. We chose USPTO patent data for two reasons. First, the US is the largest and most competitive telecommunications market in the world. Thus, it is imperative that firms competing in this market obtain US patents protection for all their key inventions. Second, the USPTO has the largest collection of patents in the world, with extensive coverage of mobile telecommunications technology. As such, US patent data is one of the best available measures of innovation output for this technology, and one that is reasonably comparable across firms.

Apart from mobile telecommunications, each firm is involved in a number of other businesses. Fig. 2 presents the bias-adjusted Herfindahl Concentration Index across

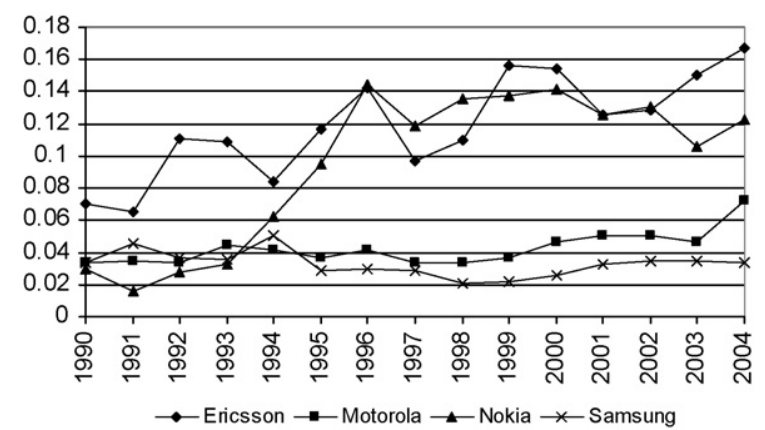

Fig. 2. Bias-adjusted Herfindahl index of patent concentration across three-digit patent classes (issue year). (a) Herfindahl index (HHI) = $\sum_{j=1}^{J}\left(N_{j} / N\right)^{2}$, where a set of $N$ patents falling into $J$ patent classes, with $N_{j}$ patents in each class. As shown by Hall et al. (2001), the HHI measure is biased upward when the number of patents on which it is based is small. They provided an unbiased measure of the true concentration: $\mathrm{HHI}$ adjusted $=(N \mathrm{HHI}-1) /(N-1)$. (b) Before 1990 , the small number of patents makes the curves erratic, which is thus not shown. (c) Based on current primary class. all patent classes for each company. It shows how concentrated patents are across classes within each firm, not the concentration of each firm's patents across the industry. While Ericsson and Nokia concentrate a great deal of their innovation effort in a small number of technological classes, Motorola and Samsung are more highly diversified into other technological fields. Hence, there is a need to constrain our analysis to the patents of each firm that are of direct relevance to mobile telecommunications. We follow Tong (1999) ${ }^{8}$ in focusing on patents having one of the four primary patent classes relevant to mobile telecommunications: class 370 (Multiplex Communications), class 375 (Pulse or Digital Communications), class 379 (Telephonic Communications), and class 455 (Telecommunications). We then searched every patent document of the four companies in these classes (370, 375,379 and 455) for keywords 9 relating to mobile telecommunications, and found these to constitute 87.2, $74.4,75.1$ and $91.2 \%$ of the patents in each class, respectively. Thus, it appears that constraining our analysis to the patents in these four US patent classes provides a reasonable proxy for each firm's mobile telecommunications patents, and in this paper we shall refer to them as "mobile patents". Of the 42,285 patents awarded to the four firms in our sample (1976-2004), 10,224 are mobile patents. ${ }^{10}$

We analyzed patent citations to trace knowledge flows across firms. This approach is widely used in a large number of studies, including Singh (2005), Rosenkopf and Nerkar (2001) and Jaffe et al. (1993). Several authors including von Wartburg et al. (2005) and Jaffe and Trajtenberg (2002) discussed the insights that can be derived through patent citation analysis, along with the issues involved. The analysis of backward citations (cita-

\footnotetext{
8 While Tong (1999)'s study covered only a brief period between 1996 and January 1999, we are able to explore the dynamics of competition over a much longer period. These technological classes may also include patents for fixed line telephony in addition to those for mobile telecommunications, but they are not mutually exclusive technologies.

${ }^{9}$ We searched for patents matching any of these keywords: mobile, wireless, cellular, cell, base station, paging, handset, AMPS, NMT, CDMA, GSM, TDMA, PDC, GPRS, and EDGE. As such, our dataset includes patents pertaining to mobile handsets, as well as other technologies used for mobile telecommunications, including switching equipment, multimedia, and satellites.

${ }^{10}$ Mobile patents constitute 56\% of Ericsson's and 50\% of Nokia's patents, whereas they only represent $22 \%$ of Motorola's patents and $8 \%$ of Samsung's patents. Furthermore, there is a large increase in the percentage of mobile patents since 1990 for Ericsson and Nokia, but not Motorola and Samsung. Therefore, the higher Herfindahl Concentration Index of Ericsson and Nokia as shown in Fig. 2 can be largely explained by their increasing focus on mobile telecommunications.
} 
tions made to other patents by the focal patent) can be used to identify relevant prior art and map knowledge flows. If patent $B$ cites patent $A$, this suggests patent $\mathrm{B}$ builds upon the knowledge in patent $\mathrm{A}$. In contrast to backward citations, the forward citations to a patent refer to other patents that cite the focal patent. Counts of forward citations are an indication of a patent's impact and economic value (Hall et al., 2005; Harhoff et al., 2003; Fleming and Sorenson, 2001). In this paper, we add a refinement to the forward citation analysis: we identify the most highly cited patents of each firm and study the citation patterns to these high impact patents. This offers a way to identify the degree to which each firm builds upon its own technological "crown jewels" as well as those of other firms.

Patent applicants have a legal duty to recognize all relevant prior art, with the possibility of legal prosecution if found to deliberately omit or conceal such citations. The decision to include citations is also influenced by patent examiners, who are experts in the relevant area. The role of patent examiners in patent citations suggests these citations are less likely to be "contaminated" by personal preferences over whom to cite than other bibliographic data such as citations in academic papers (Trajtenberg, 2001, p. 383). However, citations introduced by patent examiners may also distort the analysis (Alcácer and Gittelman, 2004), ${ }^{11}$ but as with most other studies we are unable to explore this issue in depth because data on examiner citations are not easily available for patents issued prior to 2001 which constitute the majority of our sample.

There are several other limitations of using patent data and patent citations (Griliches, 1990; Jaffe et al., 1993; Jaffe and Trajtenberg, 1999; Hall et al., 2001). Not all inventions are patentable: they must be novel, nonobvious, and have commercial application. Moreover, there is a large variation across industries in the degree to which firms rely upon patenting and other forms of intellectual property protection such as secrecy, trademarks and copyrights (Levin et al., 1987; Cohen et al., 2000). Fortunately, these are not serious concerns in our paper, which focuses on a single market - mobile telecommunications - with a very high patenting intensity. A separate issue is that patent citations may only track a small per-

\footnotetext{
${ }^{11}$ If patent examiners introduced a citation instead of the inventor of a patent, it is uncertain whether there was any knowledge flow from the cited patent to the inventor of the citing patent. Also, differences across examiners could lead to variations in forward citation counts unrelated to the quality of a patent. However, we have no reason to expect a bias among patent examiners towards Motorola or the other firms that might bias our sample in a systematic way.
}

centage of knowledge flows (Agrawal and Henderson, 2002). Despite being an imperfect measure of knowledge flows, patent citations are one of the few measures available, and so form a pragmatic choice. While recognizing the limitations of using patent citation data, we believe our results corroborate with the accounts of others who have studied this market, while raising new questions about the degree to which the incumbent in this case failed to capitalize on its most highly cited patents.

A separate limitation of patent data arises due to the use of each patent's issue year instead of application year in our analysis. A patent's application date is probably closer to the date of invention than its issue date. Hence the application date is preferred for tracing knowledge flows via citation analysis. Unfortunately, many of the patents applied for after 2000 had not yet been issued by end-2004, leading to right-truncation in our sample and consequently, difficulties in calculating the patent stocks of each firm. Moreover, the counter-factual we are testing against is whether firms built up intellectual property portfolios as bargaining chips and then leveraged complementary assets, rather than vice versa. Only after a patent is issued is it a credible bargaining chip. Thus, in this paper we present the results using each patent's issue year, although it is reassuring that the regression results in Tables 6 and 7 are similar (although statistically slightly weaker) using the application year instead.

\section{Results}

We begin with an analysis of each firm's patent stocks (Section 4.1), followed by an analysis of backward citations (Section 4.2) and of each firm's high impact patents (Section 4.3). Regression results are presented in Section 4.4.

\subsection{Patent stock analysis}

Table 2 shows patent counts for each firm in the four mobile patent classes (370, 375, 379, and 455). Motorola was dominant in the 1980s and most of the 1990s. Ericsson and Nokia began to catch up with Motorola in the late 1990s. By 1999, Ericsson overtook Motorola in the number of mobile patents granted, while Nokia overtook Motorola around 2002. Interestingly, we do not observe a surge in patenting by Ericsson leading up to its introduction of GSM technology around 1987, nor do we observe Nokia patenting aggressively prior to it becoming the market leader around 1998. This is consistent with industry accounts on the importance of complementary assets as the determinant of catch up by Ericsson and Nokia (support for GSM technology 
Table 2

Mobile telecommunications patents 1976-2004

\begin{tabular}{|c|c|c|c|c|c|}
\hline $\begin{array}{l}\text { Issue } \\
\text { year }\end{array}$ & Motorola & Ericsson & Nokia & Samsung & Total \\
\hline 1976 & 23 & 13 & & & 36 \\
\hline 1977 & 31 & 10 & & & 41 \\
\hline 1978 & 14 & 16 & & & 30 \\
\hline 1979 & 13 & 7 & & & 20 \\
\hline 1980 & 23 & 1 & & & 24 \\
\hline 1981 & 16 & 4 & & & 20 \\
\hline 1982 & 17 & 5 & & & 22 \\
\hline 1983 & 31 & 4 & & & 35 \\
\hline 1984 & 42 & 4 & & & 46 \\
\hline 1985 & 34 & 8 & & & 42 \\
\hline 1986 & 43 & 12 & & & 55 \\
\hline 1987 & 50 & 13 & 2 & & 65 \\
\hline 1988 & 41 & 6 & 1 & 1 & 49 \\
\hline 1989 & 57 & 8 & 3 & & 68 \\
\hline 1990 & 59 & 12 & & 5 & 76 \\
\hline 1991 & 90 & 13 & 2 & 14 & 119 \\
\hline 1992 & 130 & 27 & 9 & 11 & 177 \\
\hline 1993 & 197 & 37 & 16 & 16 & 266 \\
\hline 1994 & 210 & 51 & 27 & 19 & 307 \\
\hline 1995 & 228 & 70 & 49 & 19 & 366 \\
\hline 1996 & 299 & 141 & 59 & 34 & 533 \\
\hline 1997 & 259 & 110 & 61 & 22 & 452 \\
\hline 1998 & 355 & 251 & 146 & 82 & 834 \\
\hline 1999 & 302 & 396 & 198 & 134 & 1030 \\
\hline 2000 & 373 & 472 & 197 & 109 & 1151 \\
\hline 2001 & 246 & 415 & 209 & 141 & 1011 \\
\hline 2002 & 215 & 442 & 256 & 162 & 1075 \\
\hline 2003 & 189 & 433 & 295 & 168 & 1085 \\
\hline 2004 & 244 & 359 & 402 & 184 & 1189 \\
\hline Total & 3831 & 3340 & 1932 & 1121 & 10,224 \\
\hline
\end{tabular}

Note: A patent is identified as "mobile patent" if its current primary US class is $370,375,379$ or 455 .

in Europe, the shift towards design and marketing as the basis of competition). Given the time lag between invention and patenting, it is possible that Motorola may have been overtaken earlier than suggested by the patent data. However, from the data in Table 2 it is unlikely that Ericsson and Nokia were able to amass patent stocks close to the cumulative numbers built up by Motorola prior to overtaking Motorola in market share. Our results suggest that rather than building up an arsenal of patents to compete against or to bargain with the incumbent, Ericsson and Nokia relied on other means for their initial success, only after which did they begin to develop substantial patent portfolios.

The story with Samsung appears slightly different. Table 2 shows a sharp increase in the number of patents awarded to Samsung beginning around 1999. While this appears early relative to its increase in market share around 2003, it is much later than the ramp-up in marketing and advertising that occurred around 1994 as
Table 3

Forward citations per mobile patent

\begin{tabular}{|c|c|c|c|c|}
\hline $\begin{array}{l}\text { Issue year of } \\
\text { cited patent }\end{array}$ & Motorola & Ericsson & Nokia & Samsung \\
\hline 1976 & 13.96 & 4.69 & & \\
\hline 1977 & 14.58 & 11.90 & & \\
\hline 1978 & 28.71 & 7.37 & & \\
\hline 1979 & 7.77 & 4.00 & & \\
\hline 1980 & 14.43 & 10.00 & & \\
\hline 1981 & 19.06 & 6.00 & & \\
\hline 1982 & 16.53 & 6.40 & & \\
\hline 1983 & 15.03 & 11.50 & & \\
\hline 1984 & 20.07 & 6.25 & & \\
\hline 1985 & 20.94 & 5.38 & & \\
\hline 1986 & 22.37 & 9.08 & & \\
\hline 1987 & 35.52 & 9.00 & 5.50 & \\
\hline 1988 & 34.00 & 7.67 & 7.00 & 9.00 \\
\hline 1989 & 35.60 & 4.38 & 13.33 & \\
\hline 1990 & 21.90 & 21.17 & & 11.40 \\
\hline 1991 & 25.00 & 33.31 & 8.00 & 8.79 \\
\hline 1992 & 26.98 & 35.52 & 35.56 & 9.00 \\
\hline 1993 & 19.99 & 35.05 & 23.00 & 6.00 \\
\hline 1994 & 18.62 & 30.71 & 21.00 & 11.21 \\
\hline 1995 & 18.80 & 18.94 & 20.08 & 10.42 \\
\hline 1996 & 14.06 & 24.35 & 22.02 & 15.06 \\
\hline 1997 & 11.25 & 18.33 & 18.16 & 12.32 \\
\hline 1998 & 10.62 & 13.14 & 13.34 & 4.76 \\
\hline 1999 & 8.34 & 9.82 & 9.18 & 4.05 \\
\hline 2000 & 5.51 & 6.55 & 7.40 & 3.15 \\
\hline 2001 & 3.83 & 4.12 & 4.72 & 2.52 \\
\hline 2002 & 1.54 & 2.54 & 2.41 & 1.91 \\
\hline 2003 & 0.60 & 0.96 & 0.85 & 0.57 \\
\hline 2004 & 0.05 & 0.04 & 0.07 & 0.05 \\
\hline All years & 12.12 & 7.68 & 6.12 & 3.23 \\
\hline
\end{tabular}

reported in Section 2. The total stock of Samsung's patents by year 2004 is small relative to its number three position in terms of market share. Through additional analysis, we discovered that many of Samsung's mobile patents cover video technology (such as for encoding, decoding and compressing video signals). This reinforces the qualitative analysis in Section 2 and suggests that Samsung's entry was partly based on a strategy of differentiating through multimedia content. We now turn to citation analysis to examine knowledge flows across firms.

\subsection{Citation analysis}

Table 3 shows the average number of citations received per mobile patent for each of the four companies. ${ }^{12}$ This provides a measure for the average impact

\footnotetext{
12 It would be interesting to examine the backward citations by these patents to those of other organizations. As there are over 300,000 such
} 
of each firm's patents. The decline in the number of forward citations after 1997 is likely caused by truncation of the citation data (see Hall et al., 2001 for a discussion). For earlier periods, truncation is not an issue, and Table 3 illustrates how Motorola dominated initially but saw Ericsson and Nokia catching up with it in terms of their average patent quality by the early 1990s.

Fig. 3a-e are backward citation charts for the four companies covering five periods (1981-1985, 1986-1990, 1991-1995, 1996-2000, and 2001-2004). The arrows in the figures are percentages of each firm's backward citations made to other firms. For example, in Fig. 3c, 24.19\% of Ericsson's backward citations are to Motorola's patents, while only $1.73 \%$ of Motorola's backward citations are to Ericsson's patents. The frequency with which a company's patents cite those of another firm is a proxy for the intensity of knowledge flows from the cited company to the citing company; the frequency of self-citation is an indicator of knowledge accumulation within a company (i.e., a company's new patented inventions that are based on its own prior knowledge). As shown in Fig. 3a, Motorola dominated the first period with 140 patents, Ericsson had only 25 patents, and there was no citation link between Ericsson and Motorola. But, this first period is also quite likely to be affected by missing data-Ericsson might have learnt from Motorola' pre-1976 patents.

During the second period (Fig. 3b), Ericsson began to learn from Motorola, and Motorola became more inward-looking, as evidenced by heavy self-citations (20.4\% for $1986-1990$ versus $11.4 \%$ for $1981-1985$ ). Nokia began to build a patent portfolio with just six patents, citing its own prior innovations but making no citations to Motorola or Ericsson. During the next period (1991-1995), Ericsson and Nokia learnt intensively from Motorola, with 24.2 and $16.4 \%$ of their patent citations, respectively, made to Motorola (Fig. 3c). Motorola became even more inward-looking, with a self-citation rate of $30.6 \%$. Motorola began citing Ericsson's patents, but not Nokia's.

During the period $1996-2000,{ }^{13}$ Ericsson and Nokia continued to learn extensively from Motorola, but the citations made by Ericsson to Motorola fell from 24.2 to $15.6 \%$ (see Fig. 3d). Motorola paid closer attention to Ericsson (evidenced by increased citations to Ericsson),

citations involving many organizations, including many that have multiple name variations as recorded by the US Patent Office, we leave this as a future research opportunity.

${ }^{13}$ We performed additional citation analysis covering 1996-1998, and our results are almost identical to that of Tong (1999), thus validating the reliability of our data and analysis. (a)

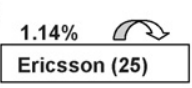

\ $11.39 \%$

Motorola (140)

(b)
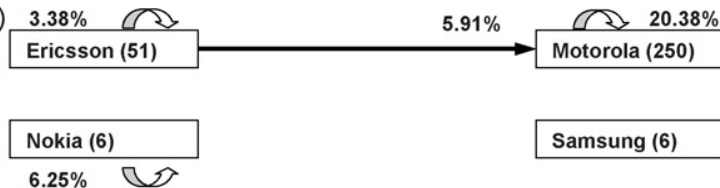

Samsung (6)

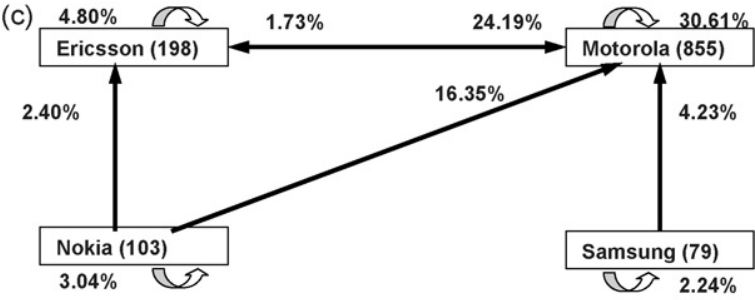

(d)
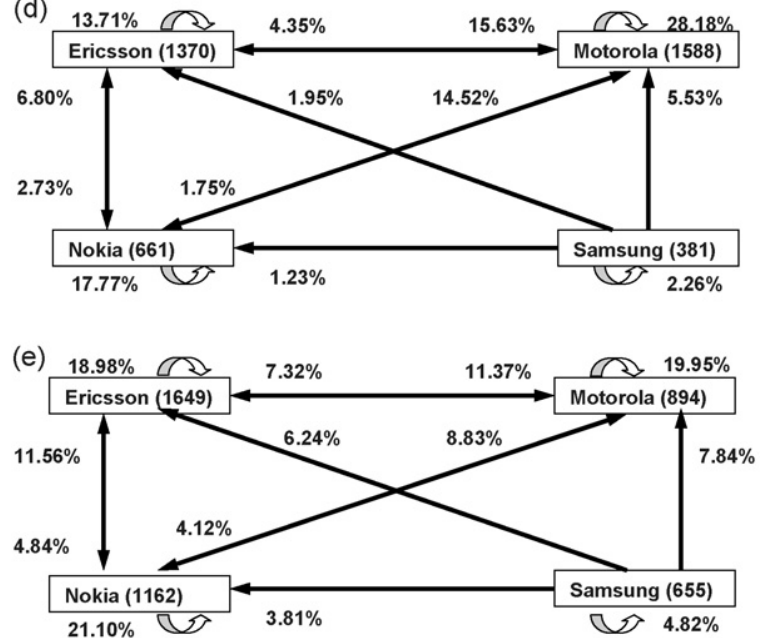

a. Number in parenthesis is the number of mobile patents issued

b. Block arrow represents self-citation.

c. Percentage is the $\%$ of citations in total citations made, $<1 \%$ not shown.

Arrow direction indicates citations to a particular company.

e. Citable patents back to those issued in 1976.

Fig. 3. (a) Backward citation chart for mobile patents 1981-1985 (issue year), (b) 1986-1990 (issue year), (c) 1991-1995 (issue year), (d) 1996-2000 (issue year) and (e) 2001-2004 (issue year).

to which it had begun to lose market share. There was also a certain degree of interaction between the two Nordic companies. Ericsson and Nokia also showed considerable accumulated capability, evidenced by augmented patent stocks and a significant increase in self-citation rates (13.7 and 17.8\%, respectively). During this period, Motorola's leadership weakened as the market migrated from analog cellular (1G) to digital cellular $(2 \mathrm{G})$, but it remained inward-looking in terms of citations. Samsung began to patent aggressively, making citations primarily to Motorola's patents. 
During the period 2001-2004 (Fig. 3e), Nokia and Ericsson's reliance on Motorola reduced substantially, with citation intensity to Motorola dropping to around $11.4 \%$ for Ericsson and $8.8 \%$ for Nokia. Motorola began to cite Ericsson's and Nokia's patents more intensively, but by then it may have been too late: in the marketplace, Motorola was overtaken by the two previous followers, especially Nokia. During this period, Motorola's patent output was much lower than in the previous period, and also fell to levels lower than both Ericsson and Nokia. Meanwhile, Samsung doubled its number of patents over the previous period, and continued to increase the extent to which it cited patents of the three other firms.

It could be argued that the above citation patterns are merely caused by the numbers of potentially citable patents available-when one company dominates the patents of an market, most patent citations will naturally be made to this company; as other firms enter the market and begin producing patents, the share of citations made to the previously dominant company is likely to fall because it now has a smaller percentage of patents that might potentially be cited. This issue is explored using regression analysis in Section 4.4.

\subsection{High impact patents}

We define a patent as a "high impact patent" if its forward citations exceed one standard deviation above the mean; this corresponds to a patent receiving 23 or more forward citations. Table 4 presents the distribution of high impact patents among the four companies. Of the 1026 high impact patents, 594 are owned by Motorola. This is more than the total of the other three companies combined. Nonetheless, the data in Table 4 should be interpreted with caution because of truncated citations for the later years.

Interestingly, Motorola's high impact patents were cited to a greater extent by its competitors than by Motorola itself. Table 5 shows that among Motorola's 30 most highly cited patents in mobile telecommunications, 14 patents receive at least as many citations from Ericsson or Nokia as from Motorola itself. ${ }^{14}$ This is quite surprising, given Motorola had more potential citing (subsequent) patents to cite these valuable patents, but did not. We further find that among the 30 most highly

\footnotetext{
14 Given Samsung's recent entry, it is likely that the citation data for Samsung is unreliable due to truncation bias. Another concern is whether the 14 patents are crucial for newly arising technologies such as GSM. Table 5 shows that at least 8 of Motorola's top 30 patents are GSM related. Five of these eight patents are cited by Ericsson or Nokia a larger number of times than by Motorola itself.
}

Table 4

Number of high impact mobile patents

\begin{tabular}{lccccr}
\hline Issue year & Motorola & Ericsson & Nokia & Samsung & Total \\
\hline 1976 & 4 & & & & 4 \\
1977 & 5 & 2 & & & 7 \\
1978 & 4 & 2 & & & 6 \\
1979 & 1 & & & & 1 \\
1980 & 6 & & & & 6 \\
1981 & 4 & & & & 4 \\
1982 & 5 & & & & 5 \\
1983 & 8 & & & & 8 \\
1984 & 13 & & & & 13 \\
1985 & 12 & & & & 12 \\
1986 & 14 & 1 & & & 15 \\
1987 & 25 & 1 & & & 26 \\
1988 & 18 & & & & 18 \\
1989 & 30 & & 1 & & 31 \\
1990 & 20 & 5 & & 1 & 26 \\
1991 & 33 & 5 & & 1 & 39 \\
1992 & 55 & 15 & 5 & 1 & 76 \\
1993 & 62 & 22 & 8 & & 92 \\
1994 & 65 & 23 & 10 & 3 & 101 \\
1995 & 64 & 22 & 13 & 1 & 100 \\
1996 & 50 & 58 & 27 & 6 & 141 \\
1997 & 29 & 33 & 25 & 2 & 89 \\
1998 & 36 & 37 & 19 & 4 & 41 \\
1999 & 20 & 33 & 14 & 4 & \\
2000 & 9 & 12 & 9 & & \\
2001 & 2 & 2 & 4 & & \\
2002 & & 1 & & & \\
Total & 594 & 274 & 135 & 23 & \\
\hline & & & & \\
\hline
\end{tabular}

Note: A mobile patent is a high impact one if it receives 23 or more citations $(>$ mean + one S.D. $=8.56+14.31=22.87)$.

cited patents owned by Ericsson, Nokia and Samsung, the corresponding number of patents cited more highly by one of the three remaining competitors is 1,4 and 6 , respectively, which are much lower than the 14 in the case of Motorola. Surely, a company can be expected to cite its most valuable patents more often than other companies, due to better awareness of R\&D being performed within the firm as well as a conscious effort to protect its own technologies. Moreover, given the legal requirement for novelty and expected commercial value when applying for patents, our findings suggest that Motorola was not as aggressive as its competitors in creating and patenting follow-on innovations that built upon the knowledge contained in its earlier patents.

Based on the analysis above, the overall picture that emerges is that Motorola enjoyed a leadership position well into the mid-1990s; Ericsson and Nokia benefited from knowledge spillovers from Motorola by heavily citing its high impact patents. Motorola was generally inward-looking and relied heavily on self-citations (perhaps even missing out on external technological 
Table 5

Motorola's 30 most cited mobile patents

\begin{tabular}{|c|c|c|c|c|c|c|}
\hline \multirow[t]{2}{*}{ Patent number } & \multirow[t]{2}{*}{ Issue year } & \multicolumn{4}{|c|}{ Number of forward citations } & \multirow{2}{*}{$\begin{array}{l}\text { Is this a GSM } \\
\text { patent? }\end{array}$} \\
\hline & & $\begin{array}{l}\text { No. of times cited } \\
\text { by Motorola }\end{array}$ & $\begin{array}{l}\text { No. of times cited } \\
\text { by Ericsson }\end{array}$ & $\begin{array}{l}\text { No. of times cited } \\
\text { by Nokia }\end{array}$ & $\begin{array}{l}\text { No. of times cited } \\
\text { by Samsung }\end{array}$ & \\
\hline 4785463 & 1988 & 9 & 0 & 1 & 0 & \\
\hline 4833701 & 1989 & 24 & 18 & 7 & 0 & Yes $^{\mathrm{a}}$ \\
\hline 4989230 & 1991 & 19 & 22 & 7 & 0 & \\
\hline 4654867 & 1987 & 27 & 13 & 2 & 1 & Yes $^{\mathrm{a}}$ \\
\hline 5127042 & 1992 & 14 & 17 & 7 & 0 & \\
\hline 4887265 & 1989 & 11 & 34 & 13 & 1 & $\mathrm{Yes}^{\mathrm{a}, \mathrm{b}}$ \\
\hline 4797947 & 1989 & 7 & 12 & 2 & 0 & Yes $^{\mathrm{b}}$ \\
\hline 4775999 & 1988 & 19 & 17 & 5 & 0 & \\
\hline 4578815 & 1986 & 28 & 26 & 1 & 0 & \\
\hline 4128740 & 1978 & 24 & 18 & 0 & 0 & Yes $^{\mathrm{a}}$ \\
\hline 4701934 & 1987 & 4 & 1 & 2 & 0 & \\
\hline 4485486 & 1984 & 32 & 27 & 0 & 0 & \\
\hline 5119504 & 1992 & 16 & 18 & 0 & 1 & Yes $^{\mathrm{b}}$ \\
\hline 5020091 & 1991 & 4 & 10 & 3 & 0 & \\
\hline 5442553 & 1995 & 1 & 0 & 1 & 0 & \\
\hline 5117449 & 1992 & 12 & 4 & 1 & 6 & \\
\hline 5095500 & 1992 & 16 & 18 & 2 & 0 & Yes $^{\mathrm{b}}$ \\
\hline 4737978 & 1988 & 14 & 26 & 5 & 0 & \\
\hline 5584054 & 1996 & 14 & 8 & 17 & 2 & \\
\hline 4737976 & 1988 & 16 & 3 & 2 & 0 & \\
\hline 5303297 & 1994 & 5 & 24 & 5 & 1 & \\
\hline 4704734 & 1987 & 18 & 7 & 1 & 1 & \\
\hline 4845772 & 1989 & 22 & 9 & 10 & 1 & \\
\hline 5579535 & 1996 & 6 & 4 & 5 & 0 & \\
\hline 4012597 & 1977 & 37 & 24 & 3 & 0 & \\
\hline 4837800 & 1989 & 1 & 8 & 8 & 1 & \\
\hline 5038399 & 1991 & 20 & 26 & 2 & 0 & Yes $^{\mathrm{b}}$ \\
\hline 5390238 & 1995 & 1 & 0 & 0 & 0 & \\
\hline 4593155 & 1986 & 22 & 10 & 2 & 0 & \\
\hline 5260988 & 1993 & 7 & 20 & 9 & 0 & \\
\hline
\end{tabular}

In bold: Motorola's top 30 patents that are cited at least as many times by Ericsson, Nokia or Samsung as by Motorola itself.

${ }^{a}$ Identified by Bekkers et al. (2002) as an essential GSM patent.

b "GSM" or "TDMA" appears in the patent document.

breakthroughs by its competitors), yet Motorola was not inward-looking enough where its high impact patents were concerned. In the following section, we use regression techniques to explore whether these findings hold up in a more formal analysis.

\subsection{Regression analysis}

Logistic regression is used to examine each company's propensity to make self-citations (base = Motorola). A company's share of "prior art" in mobile telecommunications technology is likely to be positively related to its probability of self-citation. The creation of technological capabilities is an accumulative process, and a firm's ability to generate innovations is a function of its existing technological knowledge (Cohen and Levinthal, 1990). Thus, if a company has a large share of prior patents awarded for mobile telecommunications, it will tend to cite itself more often. We therefore construct the following variable: firm $j$ 's share of mobile patent stocks in year $t=100 \times($ firm $j$ 's mobile patent stock in year $t) /($ USPTO pool of mobile patent stock in year $t$ ).

To construct this variable, we must first calculate patent stocks for each firm-year. We do so by cumulating each firm's patents per year (a flow variable) into a stock measure. Since each firm's knowledge stock depreciates over time, ${ }^{15}$ we follow Hall et al. (2000) in using a

\footnotetext{
15 On the one hand, knowledge becomes obsolete and therefore a patent is less likely to be cited as time elapses. On the other hand, knowledge diffuses and accessibility to new knowledge grows with time. However, since we are focusing on self-citations, there is reason to believe that the impact of knowledge diffusion is marginal in intra-firm knowledge flows, at least relative to inter-firm knowledge flows (see
} 
Table 6

Logistic regression for the probability of making backward self-citation (citing patents: mobile patents of the four companies issued 1981-2004, citable patents: all patents issued 1976-2004)

\begin{tabular}{|c|c|c|c|c|}
\hline Variable & Model 1 & Model 2 & Model 3 & $\begin{array}{l}\text { Model } 4 \text { (excluding } \\
\text { satellite patents) }\end{array}$ \\
\hline Constant & $-3.492(0.389)^{* * *}$ & $-2.232(0.600)^{* * *}$ & $-2.925(0.328)^{* * *}$ & $-2.033(0.643)^{* *}$ \\
\hline Share of mobile patent stock & $0.262(0.029)^{* * *}$ & $0.180(0.042)^{* * *}$ & $0.179(0.036)^{* * *}$ & $0.141(0.045)^{* *}$ \\
\hline Share of non-mobile patent stock & $0.007(0.005)$ & $0.001(0.006)$ & $0.003(0.005)$ & $0.001(0.006)$ \\
\hline $\log ($ No. of backward citations made +1$)$ & $1.302(0.044)^{* * *}$ & $1.297(0.044)^{* * *}$ & $1.292(0.043)^{* * *}$ & $1.320(0.047)^{* * *}$ \\
\hline No. of inventors & $0.037(0.018)^{*}$ & $0.037(0.018)^{*}$ & $0.036(0.018)^{*}$ & $0.034(0.020)$ \\
\hline No. of assignees & $-0.755(0.263)^{* *}$ & $-0.728(0.263)^{* *}$ & $-0.773(0.262)^{* *}$ & $-0.600(0.268)^{*}$ \\
\hline Motorola*Post 2000 & Not included & $-0.576(0.208)^{* *}$ & $-0.512(0.168)^{* *}$ & $-0.723(0.228)^{* *}$ \\
\hline Ericsson & $-0.100(0.198)$ & $-0.743(0.308)^{*}$ & $-0.638(0.260)^{*}$ & $-0.883(0.328)^{* *}$ \\
\hline Nokia & $0.051(0.203)$ & $-0.823(0.378)^{*}$ & $-0.727(0.312)^{*}$ & $-1.029(0.406)^{*}$ \\
\hline Samsung & $-1.182(0.211)^{* * *}$ & $-1.797(0.307)^{* * *}$ & $-1.790(0.266)^{* * *}$ & $-2.043(0.335)^{* * *}$ \\
\hline Class 375 & $0.094(0.071)$ & $0.100(0.071)$ & $0.107(0.070)$ & $0.158(0.076)^{*}$ \\
\hline Class 379 & $-0.359(0.095)^{* * *}$ & $-0.356(0.095)^{* * *}$ & $-0.351(0.095)^{* * *}$ & $-0.290(0.100)^{* *}$ \\
\hline Class 455 & $0.619(0.057)^{* * *}$ & $0.621(0.057)^{* * * *}$ & $0.634(0.056)^{* * *}$ & $0.652(0.062)^{* * * *}$ \\
\hline Issue year dummies & Included & Included & Not included & Included \\
\hline Year trend & Not included & Not included & $0.027(0.017)$ & Not included \\
\hline McFadden $R^{2}$ & 0.190 & $0.191\left(\Delta R^{2}=0.001^{* *}\right)$ & 0.188 & 0.191 \\
\hline$N$ & 10073 & 10073 & 10073 & 8684 \\
\hline Observations with DV $=1$ & 5787 & 5787 & 5787 & 4838 \\
\hline Observations with $\mathrm{DV}=0$ & 4286 & 4286 & 4286 & 3846 \\
\hline
\end{tabular}

$\mathrm{DV}=1$ if a patent makes one or more backward self-citations, otherwise DV $=0$. Yearly depreciation rate of patent stock $=15 \%$.

a A patent is defined as "satellite patent" if "satellite" appears in anywhere of the patent document. Among 10224 mobile patents of the four companies 1976-2004, there are 1394 satellite patents (539 from Ericsson, 679 from Motorola, 116 from Nokia, and 60 from Samsung). Among 10073 mobile patents of the four companies 1981-2004, 1389 patents involve satellite technology (536 from Ericsson, 677 from Motorola, 116 from Nokia, and 60 from Samsung).

${ }^{*} p<.05$, two-tailed test, standard error in parenthesis.

** $p<.01$, two-tailed test, standard error in parenthesis.

*** $p<.001$, two-tailed test, standard error in parenthesis.

declining balance formula and a depreciation rate of $15 \%$ (using 10 and $20 \%$ generate nearly identical results). In addition, we construct a separate variable for each firm's share of non-mobile patent stock because there might be inter-industry spillovers from other technology areas to the four patent classes under study.

Table 6 presents logistic regression results for the probability of making backward self-citations. The unit of analysis is a patent. The dependent variable is set to one if the patent makes one or more citations to same firm's prior patents, and zero otherwise. Apart from each firm's share of mobile patent stocks, year dummies are included to control for fixed effects across citations within the same issue year. Patent classes fixed effects (base $=$ Class 370) are included to account for differences across technology fields. The number of backward citations is further included as a control using the variable $\log ($ No. of backward citations made +1$)$, since a focal

Hall et al., 2001 for a detailed discussion on the impact of knowledge decay and knowledge diffusion). patent that makes a greater number of citations is also more likely to include a self-citation. We also control for the number of inventors and assignees listed in each patent document, using the variables No. of inventors and No. of assignees, respectively.

Model 1 of Table 6 pools all Motorola patents, while Models 2 and 3 use a dummy variable to split the pre2000 patents from post-2000 ones in order to account for Motorola's shift in strategy around 1999 which was discussed earlier. The difference between Models 2 and 3 is the use of a year trend instead of year dummies. Both models show that Ericsson, Nokia and Samsung are less likely to make self-citations than Motorola, even after controlling for each firm's share of mobile patent stocks and other factors. The coefficient for share of mobile patent stock is positive and significant as expected. It is interesting to note the negative and significant coefficient for Motorola*post 2000, suggesting a shift in strategy towards being less inward-looking by Motorola in recent years. We re-ran these logistic regressions using other similar variables (Ericsson*Post1995, Nokia*Post1995, Samsung*Post2000) to test whether Ericsson, Nokia and 
Table 7

Negative binomial regression for number of backward self-citations (citing patents: mobile patents of the four companies issued 1981-2004, citable patents: all patents issued 1976-2004)

\begin{tabular}{|c|c|c|c|c|}
\hline Variable & Model 1 & Model 2 & Model 3 & $\begin{array}{l}\text { Model } 4 \text { (excluding } \\
\text { satellite patents) }\end{array}$ \\
\hline Constant & $-3.153(0.205)^{* * *}$ & $-2.026(0.315)^{* * * *}$ & $-2.505(0.176)^{* * *}$ & $-1.939(0.345)^{* * *}$ \\
\hline Share of mobile patent stock & $0.191(0.017)^{* * *}$ & $0.126(0.022)^{* * *}$ & $0.132(0.019)^{* * *}$ & $0.108(0.024)^{* * *}$ \\
\hline Share of non-mobile patent stock & $-0.003(0.003)$ & $-0.011(0.004)^{* *}$ & $-0.007(0.003)^{*}$ & $-0.012(0.004)^{* *}$ \\
\hline $\log ($ No. of backward citations made +1$)$ & $1.163(0.021)^{* * *}$ & $1.157(0.021)^{* * *}$ & $1.159(0.021)^{* * *}$ & $1.184(0.023)^{* * *}$ \\
\hline No. of inventors & $0.008(0.009)$ & $0.009(0.009)$ & $0.008(0.009)$ & $0.007(0.010)$ \\
\hline No. of assignees & $-0.173(0.137)$ & $-0.133(0.137)$ & $-0.165(0.138)$ & $-0.086(0.142)$ \\
\hline Motorola* Post2000 & Not Included & $-0.490(0.105)^{* * *}$ & $-0.371(0.082)^{* * *}$ & $-0.592(0.117)^{* * *}$ \\
\hline Ericsson & $-0.359(0.128)^{* *}$ & $-0.983(0.185)^{* * *}$ & $-0.740(0.145)^{* * *}$ & $-1.113(0.200)^{* * *}$ \\
\hline Nokia & $0.159(0.121)$ & $-0.664(0.214)^{* *}$ & $-0.401(0.165)^{*}$ & $-0.790(0.234)^{* * *}$ \\
\hline Samsung & $-0.845(0.131)^{* * *}$ & $-1.331(0.167)^{* * *}$ & $-1.282(0.145)^{* * *}$ & $-1.472(0.184)^{* * *}$ \\
\hline Class 375 & $0.035(0.038)$ & $0.039(0.038)$ & $0.045(0.038)$ & $0.115(0.041)^{* *}$ \\
\hline Class 379 & $-0.382(0.057)^{* * *}$ & $-0.380(0.057)^{* * *}$ & $-0.377(0.057)^{* * *}$ & $-0.299(0.060)^{* * *}$ \\
\hline Class 455 & $0.216(0.029)^{* * *}$ & $0.218(0.029)^{* * *}$ & $0.235(0.029)^{* * *}$ & $0.266(0.032)^{* * * *}$ \\
\hline Issue year dummies & Included & Included & Not included & Included \\
\hline Year trend & Not included & Not included & $0.012(0.009)$ & Not included \\
\hline$R^{2}$ & 0.260 & $0.275\left(\Delta R^{2}=0.015^{* * *}\right)$ & 0.265 & 0.273 \\
\hline$N$ & 10073 & 10073 & 10073 & 8684 \\
\hline
\end{tabular}

$\mathrm{DV}=$ Number of backward self-citations. Yearly depreciation rate of patent stock $=15 \%$.

a As in Table 6.

${ }^{*} p<.05$, two-tailed test, standard error in parenthesis.

** $p<.01$, two-tailed test, standard error in parenthesis.

*** $p<.001$, two-tailed test, standard error in parenthesis.

Samsung became increasingly self-reliant after becoming important players in the mobile market. The estimated coefficients are positive and significant in each case $(0.985,0.869$, and 0.961 , respectively). Hence, while Motorola became significantly less likely to make self-citations after it lost its market leadership position, Ericsson, Nokia and Samsung became significantly more likely to make self-citations when they posed serious threats to the leader. This is consistent with the citation analysis in Section 4.2.

Table 7 presents negative binomial regressions, with the dependent variable being the number of backward self-citations made by each company's mobile patents. We do not use a Poisson model because it assumes equal mean and variance of the dependent variable, which is not the case for our data. Negative binomial models can accommodate for over-dispersion by assuming that the mean follows a gamma distribution (Hausman et al., 1984; Cameron and Trivendi, 1998). Table 7 reinforces the results of Table 6: Ericsson, Nokia and Samsung each has a lower self-citation rate than Motorola. This suggests that Ericsson, Nokia and Samsung relied more heavily on external knowledge than Motorola, in line with the citation analysis of Fig. 3a-e. Motorola itself switched gears and made significantly fewer selfcitations after 2000. As in Table 6, the coefficient for share of mobile patent stock is positive and significant. Interestingly, the share of non-mobile patent stock is negative and significant, indicating that the mobile business might be competing for innovation resources with other business areas.

Tables 6 and 7 suggest that Motorola was generally more inward-looking than Ericsson, Nokia and Samsung, even after controlling for various factors including its large share of mobile patent stocks. It could be argued that the results are an aberration because Motorola intentionally had a different focus, specifically that it was trying to develop its Iridium satellite-based mobile network. As a robustness check, we include a specification to Tables 6 and 7, in which we drop all patents for satellite technology related to mobile telecommunications (Model 4). This does not materially change the results.

We next investigate whether Motorola paid enough attention to its high impact patents. Table 8 presents negative binomial regressions, with the dependent variable being the number of forward self-citations received by each firm's high impact patents. As before, the base case is Motorola and similar control variables are used. But here we are studying forward citations received instead of backward citations made, so instead of each firm's share of mobile patent stocks, we control for the number of future patents (till 2004) that exist and might 
Table 8

Negative binomial regression for number of forward self-citations received by high impact mobile patents

\begin{tabular}{|c|c|c|c|c|}
\hline Variable & Model 1 & Model 2 & $\begin{array}{l}\text { Model } 3 \text { Excluding } \\
\text { "Satellite Patent"a }\end{array}$ & $\begin{array}{l}\text { Model } 4 \text { excluding } \\
\text { "Satellite Patent"a }\end{array}$ \\
\hline Constant & $-4.124(0.382)^{* * *}$ & $-3.840(0.599)^{* * *}$ & $-4.204(0.409)^{* * *}$ & $-3.826(0.649)^{* * *}$ \\
\hline No. of following mobile patents $/ 1000^{\mathrm{b}}$ & $0.727(0.145)^{* * * *}$ & $0.706(0.149)^{* * *}$ & $0.548(0.156)^{* * *}$ & $0.521(0.160)^{* *}$ \\
\hline No. of following other patents $/ 1000^{\mathrm{b}}$ & $-0.025(0.037)$ & $-0.035(0.041)$ & $0.021(0.040)$ & $0.007(0.044)$ \\
\hline $\log ($ no. of forward citations received +1$)$ & $0.865(0.058)^{* * *}$ & $0.864(0.058)^{* * *}$ & $0.897(0.064)^{* * * *}$ & $0.894(0.064)^{* * *}$ \\
\hline No. of inventors & $0.025(0.018)$ & $0.026(0.018)$ & $0.024(0.020)$ & $0.025(0.020)$ \\
\hline No. of assignees & $0.438(0.271)$ & $0.439(0.271)$ & $0.504(0.287)$ & $0.508(0.287)$ \\
\hline Ericsson & $0.389(0.257)$ & $0.344(0.268)$ & $0.706(0.279)^{*}$ & $0.644(0.291)^{*}$ \\
\hline Nokia & $1.570(0.149)^{* * *}$ & $1.499(0.188)^{* * * *}$ & $1.738(0.162)^{* * *}$ & $1.643(0.206)^{* * *}$ \\
\hline Samsung & $0.973(0.417)^{*}$ & $0.990(0.418)^{*}$ & $0.292(0.461)$ & $0.317(0.463)$ \\
\hline Class 375 & $0.096(0.080)$ & $0.093(0.081)$ & $0.146(0.089)$ & $0.141(0.089)$ \\
\hline Class 379 & $-0.055(0.115)$ & $-0.054(0.115)$ & $-0.018(0.123)$ & $-0.018(0.123)$ \\
\hline Class 455 & $0.245(0.059)^{* * * *}$ & $0.245(0.059)^{* * * *}$ & $0.227(0.064)^{* * *}$ & $0.228(0.064)^{* * *}$ \\
\hline Year trend ${ }^{c}$ & & $-0.008(0.013)$ & & $-0.010(0.014)$ \\
\hline$R^{2}$ & 0.413 & 0.415 & 0.423 & 0.426 \\
\hline$N$ & 1026 & 1026 & 878 & 878 \\
\hline
\end{tabular}

DV = Number of forward self-citations received. Samsung only had 23 out of the 1026 high impact mobile patents (2.2\%).

a A patent is defined as a "satellite patent" if the word "satellite" appears in anywhere of the patent document. Among 1026 high impact mobile patents of the four companies 1976-2004, there are 148 patents related to satellite technology (47 from Ericsson, 89 from Motorola, 9 from Nokia, and 3 from Samsung).

${ }^{\mathrm{b}}$ Unlike in Tables 6 and 7, we do not depreciate following patent stock in this regression. This is because high impact mobile patents are likely to have different knowledge depreciation rates than an average patent. High impact patents probably exhibit less knowledge decay over time, so we count the number of potentially citing patents without assuming the degree to which earlier forward citations are more important than later forward citations.

${ }^{c}$ Year dummies are not used because in certain years, these four companies had a very small number of high impact mobile patents (e.g. one each for 1979 and 2002).

* $p<.05$, two-tailed test, standard error in parenthesis.

** $p<.01$, two-tailed test, standard error in parenthesis.

${ }^{* * *} p<.001$, two-tailed test, standard error in parenthesis.

cite each high impact patent (this approach is analogous to Hall et al., 2005). The variable used for this is No. of following mobile patents, which is the number of mobile patents of each firm having an issue date after the focal one. Another variable, $\log$ (No. of forward citations received +1 ) controls for the overall impact of each patent.

The results in Table 8 show that Ericsson and Nokia made more self-citations to their high impact patents than Motorola. While the estimated coefficient for Nokia is positive and significant across all specifications, that for Ericsson is positive, but becomes statistically significant only after dropping patents for satellite technology used in mobile telecommunications (Models 3 and 4). The results for Samsung are harder to interpret. While the estimated coefficient for Samsung is positive and significant when all of its high impact patents are included (Models 1 and 2), it becomes statistically insignificant once we remove "satellite patents". We believe this is due to Samsung's late entry coupled with right-truncation of the patent data, so we are only able to observe 23 "high impact" patents by Samsung out of the 1026 in the sample. ${ }^{16}$

In Table 9, we compare Motorola and its followers' reaction to each others' high impact patents. Duration/survival analysis is used because the data is right censored: citations by patents issued after 2004 are not observed. We use Cox (1972) regressions to examine the impact of patent age on the hazard of a high impact patent being cited. The year trend is positive and significant in Model 1, but not in Model 2. Thus, we find that as time progresses, Motorola's high impact patents are more likely to be cited by Ericsson or Nokia or Samsung at any given point of time. However, a similar pattern is not found for Motorola, i.e., over the years, Motorola was not becoming more responsive to its key competitors' high impact patents.

\footnotetext{
16 We subsequently found that Samsung's three "satellite patents" were actually multimedia patents that were misclassified. Putting these back in, we obtain an estimated coefficient for Samsung of 0.663 (with standard error $=0.439$ ) for Model 4 of Table 8 .
} 
Table 9

Cox regression for high impact mobile patents hazard rate

\begin{tabular}{lcc}
\hline Variable & $\begin{array}{l}\text { Model 1 (Ericsson/ } \\
\text { Nokia/Samsung } \\
\text { citing Motorola) }\end{array}$ & $\begin{array}{l}\text { Model 2 (Motorola } \\
\text { citing Ericsson/ } \\
\text { Nokia/Samsung) }\end{array}$ \\
\hline $\begin{array}{l}\text { No. of forward } \\
\quad \text { citations received }\end{array}$ & $0.008(0.002)^{* * *}$ & $0.011(0.002)^{* * *}$ \\
No. of inventors & $0.063(0.034)$ & $0.040(0.049)$ \\
No. of assignees & $0.753(1.011)$ & $0.991(0.418)^{*}$ \\
Class 375 & $-0.548(0.147)^{* * *}$ & $-0.159(0.214)$ \\
Class 379 & $-0.636(0.248)^{*}$ & $-0.460(0.277)$ \\
Class 455 & $0.110(0.110)$ & $0.256(0.136)$ \\
Year trend & $0.088(0.010)^{* * *}$ & $-0.002(0.019)$ \\
Chi-square & 116.670 & 43.449 \\
Probability & 0.000 & 0.000 \\
$N$ & 594 & 432 \\
Number of right & 67 & 127 \\
$\quad$ censored cases & & \\
\hline
\end{tabular}

Cox regression estimates the influence of each explanatory variable on a baseline hazard function. A negative (positive) coefficient means that the hazard (the risk of a high impact mobile patent to be cited) is reduced (increased)

a DV in Model $1=$ hazard rate of a Motorola high impact mobile patent being cited by Ericsson/Nokia/Samsung.

b DV in Model 2 =hazard rate of an Ericsson/Nokia/Samsung high impact mobile patent being cited by Motorola.

${ }^{*} p<.05$, two-tailed test, standard error in parenthesis.

${ }^{* *} p<.01$, two-tailed test, standard error in parenthesis.

**** $p<.001$, two-tailed test, standard error in parenthesis.

\section{Discussion and conclusions}

Our case analysis illustrates how three firms attempted to catch up with the market leader in the mobile telecommunications market. In each case, the challenger initially penetrated the market by leveraging complementary assets (new customers, complementary technologies, branding and marketing). This gave the entrant a foothold in the market that it subsequently expanded by investing in $R \& D$ to develop a portfolio of patented innovations. Our analysis shows that knowledge flows from the leader to the follower play an important role in the catching up process. The market leader often spends a tremendous amount of resources on developing new technologies (such as Motorola's 15-year, US\$ 100 million investment in DynaTAC, the world's first commercial portable telephone). A follower can capitalize on knowledge spillovers from the leader in order to catch up with the latter, probably utilizing far fewer resources albeit with a time lag. As the follower gradually builds up its own innovation capability, it continues to rely heavily on the leader for knowledge. Only around the time it overtakes the incumbent and becomes the new leader does the challenger significantly reduce its dependence on the leader and start building its own technological prowess. These patterns are reflected in our analysis of mobile telecommunications patents and citations.

Our paper makes several contributions to the literature. First, we extend the Gans-Stern (2003) framework by incorporating de alio entry. In the Gans-Stern framework, when the incumbent is strong in both intellectual property and complementary assets, new entry in the form of de novo entry appears to be excluded. However, our paper shows that entry may still be possible, in the form of de alio firms. Second, while it is well known that complementary assets are important for de alio entry (Carroll et al., 1996), our paper suggests that complementary assets, while necessary for entry, are not sufficient to catch up with (let alone overtake) the incumbent leader. To achieve this, a de alio entrant must not only leverage its complementary assets, but also learn from knowledge spillovers and invest in R\&D to progressively strengthen its intellectual property position relative to the leader. However, the sequencing of investment priority appears important: the de alio entrant should invest in exploiting its complementary assets to gain market entry early, even while it is still in the process of building up its technological capabilities, rather than wait until it has achieved substantial parity in technology with the leader, as the conventional technology race literature may suggest. Overall, our proposed extension of the Gans-Stern (2003) framework helps to integrate several important ideas in the literature: the foundations put forward by Teece (1986), strategies for entrepreneurial (de novo) entry (Gans et al., 2002) and recent work on de alio entry (Agarwal et al., 2004; Helfat and Lieberman, 2002; Klepper and Simons, 2000). We believe that using a single framework to analyze both de novo and de alio entry along the dimensions of intellectual property and complementary assets will enhance the value of the already useful Gans-Stern framework, particularly for managers and policy makers.

Another important contribution of our paper is with regards to the literature on knowledge flows. While several studies have suggested that knowledge spillovers from leading firms are important (e.g. Cockburn and Henderson, 1994; Khanna, 1995), such spillovers have not been examined in detail. Our analysis of knowledge flows within and across a small number of firms (Ericsson, Motorola, Nokia and Samsung) over an extended period of time offers an interesting view of the rich dynamics at work. On the one hand, Motorola was too inward-looking in developing new technology, as is consistent with the not-invented-here (NIH) syndrome (Katz and Allen, 1982). On the other hand, we show 
that Motorola was paradoxically not inward-looking enough in leveraging its high impact patents. Interestingly, Bekkers et al. (2002) found that Motorola had the largest share of essential patents in GSM technology (Motorola had 27 out of 140 such patents, while Nokia took second place with 19 such patents). Yet, Motorola missed the shift to GSM: although it aggressively licensed its GSM patents to others and charged handsome royalty fees, it did not further exploit these patents as fast as its key competitors. In an interview with Fortune Magazine (Lashinsky, 2004, p. 59), Thomas J. Lynch, president of Motorola's Personal Communications Division said: "There are endless instances where this company has blazed a trail and someone else has reaped the benefits." This corroborates with our results in Table 5, which shows that five of the eight key GSM patents owned by Motorola are cited more often by its main competitors than by itself.

Our paper points to several research opportunities. It is important to explore whether the strategy articulated in this paper is observed in other settings where the incumbent firm is strong in both intellectual property and complementary assets. In this case, Motorola made several strategic mistakes that offered competitors a window of opportunity for entry. But had it not made such mistakes, would entry have even been possible, and if so would it have required more sophisticated entry strategies? Further work is also needed to explore the nature of each entrant's R\&D investments and the mechanisms by which it absorbed knowledge flows. Did the entrants rely upon internal research or joint projects with external parties? Did they extensively hire engineers and scientists with relevant prior experience, and from where? To what extent did they depend upon corporate venturing as a means of sensing market and technological trends, and for acquiring new capabilities (Birkinshaw et al., 2002)?

Another opportunity lies in the further extension of a novel methodology used in this paper-identifying citations to highly cited patents. These highly cited patents represent the most valuable ideas patented by a firm, and further work is needed to understand whether our findings about Motorola's highly cited patents also apply to other firms that stumbled in other industries.

Finally, we suggest that greater attention should be placed on the role of public policy. In the case of the mobile telecommunications market, the EU's mandatory support for GSM in Europe and the US Federal Communications Commission's decision not to impose a countrywide standard for mobile telecommunications influenced the dynamics of competition within this market. We speculate that more generally, policy affects the degree to which firms gain access to scarce com- plementary assets such as access to customers, natural resources, telecommunications spectrums, rights to distribute digital media, etc. Research into these issues can help elaborate upon the profound insights first suggested by Teece (1986).

\section{Acknowledgements}

We thank participants of the IEEE International Engineering Management Conference (2004) for their feedback. We also thank Albert $\mathrm{Hu}$ and three anonymous reviewers at Research Policy for invaluable advice. We acknowledge the National University of Singapore for research funding (R-313-000-056-112) and access to the NUS Patent Database. All errors and omissions remain our own.

\section{References}

Adner, R., 2002. When are technologies disruptive? A demand-based view of the emergence of competition. Strategic Management Journal 23 (8), 667-688.

Adner, R., 2003. How Nokia won the mobile revolution in the 1990s. INSEAD Case Analysis for High-Tech Entrepreneurship and Strategy, INSEAD.

Agarwal, R., Echambadi, R., Franco, A.M., Sarkar, M.B., 2004. Knowledge transfer through inheritance: Spin-out generation, development and survival. Academy of Management Journal 47 (4), 501-522.

Agrawal, A., Henderson, R., 2002. Putting patents in context: exploring knowledge transfer from MIT. Management Science 48 (1), 44-60.

Alcácer, J., Gittelman, M., 2004. How do I know what you know? Patent examiners and the generation of patent citations. mimeo.

Arrow, K.J., 1962. Economic welfare and the allocation of resources for invention. In: NBER, The Rate and Direction of Inventive Activity: Economic and Social Factors. Princeton University Press, Princeton, NJ.

Bekkers, R., Duysters, G., Verspagen, B., 2002. Intellectual property rights, strategic technology agreements and market structure: the case of GSM. Research Policy 31 (7), 1141-1161.

Birkinshaw, J., van Basten Batenburg, R., Murray, G., 2002. Venturing to succeed. Business Strategy Review 13 (4), 10-17.

Burgelman, R., Meza, P., 2003. Nokia beyond 2003: a mobile gatekeeper? Stanford Graduate School of Business Case SM-113.

Burnham, J.P., 2002. The Essential Guide to the Business of US Mobile Wireless Communications. Prentice-Hall, Upper Saddle River, NJ.

BusinessWeek, 1998. How Motorola lost its way. Issue 3576, p. 140 (4 May).

BusinessWeek, 2000. Streaming video-on your cell phone? (5 December).

Cameron, A.C., Trivendi, P.K., 1998. Regression Analysis for Count Data. Cambridge University Press, Cambridge, UK.

Carroll, G.R., Bigelow, L.S., Seidel, M.L., Tsai, L.B., 1996. The fates of de novo and de alio producers in the American automobile industry 1885-1981. Strategic Management Journal, Summer Special Issue 17, 117-137. 
Christensen, C.M., Bower, J.L., 1996. Customer power, strategic investment, and the failure of leading firms. Strategic Management Journal 17 (3), 197-218.

Cockburn, I., Henderson, R., 1994. Racing to invest? The dynamics of competition in ethical drug discovery. Journal of Economics and Management Strategy 3 (3), 481-519.

Cohen, W.M., Levinthal, D.A., 1990. Absorptive capacity: a new perspective on learning and innovation. Administrative Science Quarterly 35 (1), 128-152.

Cohen, W.M., Nelson, R.R., Walsh, J.P., 2000. Protecting their intellectual assets: appropriability conditions and why US manufacturing firms patent (or not). NBER Working Paper 7552, Cambridge, MA.

Collis, D., 1999. Nokia mobile phones: connecting countries. Working paper, Yale School of Management.

Cox, D.R., 1972. Regression models and life-tables. Journal of the Royal Statistical Society, Series B (Methodological) 34 (2), 187-220.

Echikson, W., 1994. Nokia: How to wing markets fast. Fortune 129 (11), 114.

Economist, 2001. Dialling up trouble. The Economist Global Agenda, 24 April 2001.

Euromonitor, 2005. Samsung Electronic Co. Ltd.: Global Market Information Database.

Finkelstein, S., Sanford, S.H., 2000. Learning from corporate mistakes: the rise and fall of Iridium. Organizational Dynamics 29 (2), 138-148.

Fleming, L., Sorenson, O., 2001. Technology as a complex adaptive system: evidence from patent data. Research Policy 30 (7), 1019-1039.

Gans, J.S., Hsu, D., Stern, S., 2002. When does start-up innovation spur the gale of creative destruction? RAND Journal of Economics 33 (4), 571-586.

Gans, J.S., Stern, S., 2003. The product market and the market for "ideas": Commercialization strategies for technology entrepreneurs. Research Policy 32 (2), 333-350.

Gilbert, R.J., Newbery, D.M., 1982. Preemptive patenting and the persistence of monopoly. American Economic Review 72 (3), 514-526.

Griliches, Z., 1990. Patent statistics as economic indicators. Journal of Economic Literature 28 (4), 1661-1707.

Hall, B.H., Jaffe, A.B., Trajtenberg, M., 2000. Market value and patent citations: a first look. NBER Working Paper 7741, Cambridge, MA.

Hall, B.H., Jaffe, A.B., Trajtenberg, M., 2001. The NBER patent citations data file: lessons, insights and methodological tools. NBER Working Paper 8498, Cambridge, MA.

Hall, B.H., Jaffe, A.B., Trajtenberg, M., 2005. Market value and patent citations. RAND Journal of Economics 36 (1), 16-38.

Hannan, M.T., Freeman, J.H., 1984. Structural inertia and organizational change. American Sociological Review 49 (2), 149-164.

Harhoff, D., Scherer, F.M., Vopel, K., 2003. Citations, family size, opposition, and the value of patent rights. Research Policy 32 (8), 1343-1363.

Hausman, J., Hall, B.H., Griliches, Z., 1984. Econometric models for count data with an application to the patents-R\&D relationship. Econometrica 52 (4), 909-938.

Helfat, C.E., Lieberman, M.B., 2002. The birth of capabilities: market entry and the importance of pre-history. Industrial and Corporate Change 11 (4), 725-760.

Henderson, R.M., Clark, K.B., 1990. Architectural innovation: the reconfiguration of existing product technologies and the failure of established firms. Administrative Science Quarterly 35 (1), 9-30.
IDATE, 2006. Mobile 2006: Markets and Trends. www.IDATE.org.

Jaffe, A.B., Trajtenberg, M., 1999. International knowledge flows: evidence from patent citations. Economics of Innovation \& New Technology 8 (1/2), 105-136.

Jaffe, A.B., Trajtenberg, M., 2002. Patents, Citations, and Innovations: A Window on the Knowledge Economy. MIT Press, Cambridge, MA.

Jaffe, A.B., Trajtenberg, M., Henderson, R., 1993. Geographic localization of knowledge spillovers as evidenced by patent citations. Quarterly Journal of Economics 108 (3), 577-598.

Katz, R., Allen, T.J., 1982. Investigating the Not Invented Here (NIH) syndrome: a look at the performance, tenure and communications patterns of $50 \mathrm{R} \& \mathrm{D}$ project groups. R\&D Management 12 (1), $7-19$.

Khanna, T., 1995. Racing behavior: technological evolution in the highend computer industry. Research Policy 24 (6), 933-958.

Khessina, O.M., 2002. Effects of entry mode and incumbency status on the rates of firm product innovation in the worldwide optical disk drive industry 1983-1999. University of California Information Storage Industry Center Report 2002-01.

Klepper, S., Simons, K.L., 2000. Dominance by birthright: entry of prior radio producers and competitive ramifications in the U.S. television receiver industry. Strategic Management Journal 21 (10/11), 997-1016.

Lashinsky, A., 2004. Can Moto find its mojo? Fortune 149 (7), 56-61.

Lee, B., Lee, S.J., 2004. Case study of Samsung's mobile phone business. KDI School of Public Policy and Management Working Paper 04-11.

Leonard-Barton, D., 1995. Wellsprings of Knowledge. Harvard Business School Press, Boston, MA.

Levin, R., Klevorick, A., Nelson, R.R., Winter, S.G., 1987. Appropriating the returns from industrial research and development. Brookings Papers on Economic Activity 3, 783-820.

Levitt, B., March, J.G., 1988. Organizational learning. Annual Review of Sociology 14, 319-340.

Macher, J.T., Richman, B.D., 2004. Organizational responses to discontinuous innovation: a case study approach. International Journal of Innovation Management 8 (1), 87-114.

McGahan, A.M., Vadasz, L.L., Yoffie, D.B., 1997. Creating value and setting standards: the lessons of consumer electronics for personal digital assistants. In: Yoffie, D.B. (Ed.), Competing in the Age of Digital Convergence. Harvard Business School Press, Boston, pp. 227-264.

Ong, S.W., Jeden, V.M., 2002. The mobile industry in 2002. Stanford Technology Ventures Program (STVP) Case Study, under the supervision of Kosnik, T.J. \& Wong, P.K.

Reinganum, J.F., 1983. Uncertain innovation and the persistence of monopoly. American Economic Review 73 (4), 741-748.

Rosenkopf, L., Nerkar, A., 2001. Beyond local search: boundaryspanning, exploration, and impact in the optical disk industry. Strategic Management Journal 22 (4), 287-306.

Singh, J., 2005. Collaborative networks as determinants of knowledge diffusion patterns. Management Science 51 (5), 756-770.

Steinbock, D., 2001. The Nokia Revolution. AMACOM, New York.

Steinbock, D., 2003. Mobile Horizon: Strategy and Competition in the Worldwide Mobile Marketplace. AMACOM, New York.

Teece, D.J., 1986. Profiting from technological innovation: implications for integration, collaboration, licensing, and public policy. Research Policy 15 (6), 285-305.

Tong, X.S., 1999. Analyzing technology competition between Motorola, Nokia and Ericsson through US Patent Study. mimeo. 
Trajtenberg, M., 2001. Innovation in Israel 1968-1997: a comparative analysis using patent data. Research Policy 30 (3), 363-389.

Trajtenberg, M., Henderson, R., Jaffe, A.B., 1997. University versus corporate patents: a window on the basicness of invention. Economics of Innovation \& New Technology 5 (1), 19-50.

Tushman, M.L., Anderson, P., 1986. Technological discontinuities and organizational environments. Administrative Science Quarterly 31 (3), 439-465. von Wartburg, I., Teichert, T., Rost, K., 2005. Inventive progress measured by multi-stage patent citation analysis. Research Policy 34 (10), 1591-1607.

Yin, R., 1994. Case Study Research: Design and Methods, second ed. Sage Publishing, Beverly Hills, CA.

Yu, S., 1998. The growth pattern of Samsung Electronics. International Studies of Management \& Organizations 28 (4), 57-72. 